\title{
Composition of carbon, nitrogen and phosphorus in single cells of three filamentous cyanobacteria using nuclear microprobe and traditional techniques
}

\author{
Eva Pérez Blanco ${ }^{1, *}$, Chatarina Karlsson ${ }^{1}$, Jan Pallon ${ }^{2}$, Edna Granéli ${ }^{1}$ \\ ${ }^{1}$ LnUCEEMiS - School of Natural Sciences, Linnaeus University, 39182 Kalmar, Sweden \\ ${ }^{2}$ Division of Nuclear Physics, Department of Physics, Lund University, Box 118, 22100 Lund, Sweden
}

\begin{abstract}
Intracellular of carbon, nitrogen and phosphorus content in phytoplankton cells is traditionally measured using concentrates containing thousands to millions of cells. In the present study, we used a nuclear microprobe (NMP) to determine C, N and P concentrations in single filaments of 3 cyanobacteria species: Anabaena sp., Nodularia spumigena and Aphanizomenon flosaquae var. klebahnii isolated from Baltic Sea water. Estimations of C, N and P content per cell were calculated and compared to the concentrations found using traditional bulk methods. No significant differences regarding the $\mathrm{C}, \mathrm{N}$ and $\mathrm{P}$ cellular content were found between the 2 methods for each of the species tested ( $p<0.05)$. From our results, we conclude that the NMP can be a useful tool for studying the elemental content of single phytoplankton cells.
\end{abstract}

KEY WORDS: Baltic Sea $\cdot$ Elemental cellular content $\cdot$ Nitrogen-fixing cyanobacteria $\cdot$ Nuclear microprobe $\cdot$ Nutrients

\section{INTRODUCTION}

Cellular nutrient concentrations and ratios are used to determine the state of cells, i.e. to ascertain whether their growth is limited by one or several nutrients. Traditionally, the intracellular macronutrients (carbon $[\mathrm{C}]$, nitrogen $[\mathrm{N}]$ and phosphorus $[\mathrm{P}]$ ) are analysed from a cell concentrate, thus giving the average content of a whole population when working with a monoculture, or the average content of whole communities, as well as a certain size fraction, when working with field samples. Although healthy growing phytoplankton cells have a variable nutrient content, this is concealed by the contribution of other organisms and detritus to the C:N:P ratio of plankton (Tett et al. 1985). On other occasions another approach is taken by analysing the inorganic $\mathrm{N}$ and $\mathrm{P}$ available in the water. Measurements of dissolved nutrients in the water give an indication of the nutrient status of the phytoplankton cells, particularly as varying proportions of these nutrients are biologically available (Ganf et al. 1986). However, the internal nutrient status of the phytoplankton cells is more important and a more reliable measurement to estimate nutrient sufficiency or deficiency in phytoplankton cells than the nutrient concentrations in the medium, as many species do accumulate higher amounts of the deficient nutrient when it is offered in higher amounts, the so-called 'luxury uptake' (Droop 1973). Ultimately, these factors affect different phytoplankton species growth rates in a positive or negative way (Droop 1973, 1974). The chemical forms in which a nutrient is available may also play an important role in the phytoplankton nutrient status.

Growth limitation by nutrients, such as phosphate and inorganic nitrogen, affects the population dynamics of phytoplankton in aquatic environments 
(Rhee \& Gotham 1981). Traditionally, it is thought that there is no growth limitation by $\mathrm{N}$ and $\mathrm{P}$ simultaneously. Growth is limited by $\mathrm{N}$ or $\mathrm{P}$ on either side of the optimum Redfield N:P atomic ratio of 16:1 (Rhee 1978). Nevertheless, co-limitation by 2 resources has been described at the species and community level (Arrigo 2005), including by $\mathrm{N}$ and $\mathrm{P}$ simultaneously (Seppälä et al. 1999). It is expected that when the availability of $\mathrm{N}$ or $\mathrm{P}$ control algal growth, a near-maximal growth rate will be reflected in high C:N:P ratios near the Redfield ratio (Tett et al. 1985). The Redfield ratio of 106:16:1 C:N:P (by atoms), which is related to mixed phytoplankton cells growing in the open oceans (Redfield et al. 1963), has been the basis of numerous experiments to determine if the cells are $\mathrm{N}$ and $\mathrm{P}$ sufficient or deficient. However, laboratory studies have shown that species-specific C:N:P ratios may vary significantly from the Redfield ratio (Sakshaug \& Olsen 1986), given that the Redfield N:P ratio of 16 is only an average of species-specific ratios (Klausmeier et al. 2004). Therefore, determination of the elemental ratios of cellular nutrient concentrations gives a better indication of nutrient limitation in algal cells than the quantification of the level of nutrients in the medium (Holm \& Armstrong 1981).

Within single phytoplankton cells, elements such as $\mathrm{P}$, sulfur $(\mathrm{S})$ and sodium $(\mathrm{Na})$ have been studied using X-ray microanalysis (XRMA) techniques, e.g. scanning and transmission electron microscopy (Clay et al. 1991, El-Bestawy et al. 1996, Sigee \& Holland 1997, Sigee et al. 1998, Rengefors et al. 1999). These techniques use electrons and are most suitable for heavy elements due to interfering radiation that limits the detection of lighter elements (Llabador \& Moretto 1998). However, the nuclear microprobe techniques (NMP) use protons instead of electrons, and because protons are heavier particles, they are scattered much less, improving the detection limit by 2 to 3 orders of magnitude compared to those generated using electron microanalysis. For instance, particleinduced X-ray emission allows routine analysis of an unknown sample with a precision and accuracy better than 95\% (Tapper \& Malmqvist 1991). The NMP comprises several techniques depending on the signals that are analysed. These signals can be used for qualitative or quantitative analysis. Some of these techniques have been used in life sciences studies for a number of years now (Moretto \& Llabador 1997), for instance to study the distribution of several ions on human skin cells (Pallon et al. 1996) or the nutrient status of the dinoflagellate Dinophysis norvegica (Gisselson et al. 2001). The main drawback of these techniques is that they only provide data on the elemental content of a cell, irrespective of its chemical form (Tapper \& Malmqvist 1991).

In the present study, high-energy protons were used to estimate the intracellular composition of C, N and $\mathrm{P}$ in single cyanobacterial filaments. The NMP techniques used here were particle-induced X-ray emission (PIXE) to quantify $\mathrm{P}$, proton backscattering spectrometry (BS) for $\mathrm{C}$ and $\mathrm{N}$ and scanning transmission ion microscopy (STIM; Pallon et al. 2004) to estimate the areal mass density of the sample $\left(\mathrm{mg} \mathrm{cm}^{-2}\right)$. The principles of the NMP techniques can be read elsewhere (Tapper \& Malmqvist 1991, Llabador \& Moretto 1998).

The species examined in the present study were the brackish-water filamentous cyanobacteria Anabaena sp., Nodularia spumigena and Aphanizomenon flos-aquae var. klebahnii. These species are all common components of the phytoplankton community in the Baltic Sea and have the ability to reduce $\mathrm{N}_{2}$ to $\mathrm{NH}_{4}{ }^{+}$, which can be advantageous over other species when other sources of inorganic nitrogen become unavailable (Smith 1983). The most abundant species in the yearly recurrent cyanobacterial blooms in the Baltic Sea are the non-toxic Aphanizomenon flos-aquae and the hepatotoxic Nodularia spumigena (Vahtera et al. 2007). Anabaena sp., also hepatotoxic, is also present but usually represents $<10 \%$ of the total community cell numbers (EngströmÖst et al. 2011).

The aim of the present study was to investigate how the NMP techniques compare to traditional bulk techniques with respect to quantifying the $\mathrm{C}, \mathrm{N}$ and $P$ cellular content of 3 cyanobacteria species. Information on the nutrient variability within individual filaments in the population is also given.

\section{MATERIALS AND METHODS}

\section{Algal strains}

The 3 cyanobacteria species used in the present study were isolated from Baltic Sea waters and kept at the Kalmar Algae Collection (KAC, Linnaeus University, Kalmar, Sweden). The 3 species were: Anabaena sp. (KAC 6) isolated in Askö in the Stockholm archipelago, Nodularia spumigena (KAC 10) and Aphanizomenon flos-aquae var. klebahnii (KAC 15), both isolated from the Kalmar Sound. For simplification, we will refer to species KAC 15 as A. flos-aquae hereafter. The 3 species were grown separately in a $500 \mathrm{ml}$ batch culture with $\mathrm{f} / 2$ medium, salinity 7 , 
$16^{\circ} \mathrm{C}$, under $240 \mu \mathrm{E} \mathrm{m} \mathrm{m}^{-2} \mathrm{~s}^{-1}$ irradiation with a $16 \mathrm{~h}$ light:8 $\mathrm{h}$ dark cycle. Once the cultures entered the exponential phase, samples from each of the 3 cultures were taken for particulate $\mathrm{C}, \mathrm{N}$ and $\mathrm{P}$ analyses using the NMP and traditional bulk methods.

\section{Nuclear microprobe analyses}

The samples analysed by the NMP method were prepared as described in Gisselson et al. (2001) with minor modifications. Briefly, $10 \mathrm{ml}$ of each culture were filtered through a $20 \mu \mathrm{m}$ mesh size nylon net. Then, the filters were rinsed twice with $30 \mathrm{ml}$ of icecold Milli-Q water to remove extracellular $\mathrm{NaCl}$ and thus avoid the deposition of salt crystals in the sample. No vacuum was applied during filtrations. The filaments were then transferred to a plastic film, Kimfol ${ }^{\circledR}$, by lightly pressing the nylon net to the film. The filaments were then stored at $-20^{\circ} \mathrm{C}$ for $\sim 1 \mathrm{~h}$ before freeze-drying for $2 \mathrm{~h}$ (Braun-Christ Alpha 2-4). After freeze-drying, the samples were stored in a desiccator until analysis. The time between rinsing and freezing was minimised to reduce osmotic shock. A total of 14 to 16 filaments ( 400 cells for Anabaena sp. and >1000 cells for Aphanizomenon flos-aquae and for Nodularia spumigena) of each species were analysed with PIXE, BS and STIM. Results of C, N and $\mathrm{P}$ cellular content were converted to $\mathrm{pmol} \mathrm{cell}{ }^{-1}$. The microprobe was calibrated according to Pallon et al. (1999) to allow the calculation of elemental content measured with these techniques.

\section{Elemental analyses using bulk methods}

For $\mathrm{C}, \mathrm{N}$ and $\mathrm{P}$ analyses using bulk methods, 4 aliquots of $50 \mathrm{ml}$ ( 2 for $\mathrm{C}$ and $\mathrm{N}$ and 2 for $\mathrm{P}$ ) of each culture were filtered through a pre-combusted $\left(450^{\circ} \mathrm{C}, 2 \mathrm{~h}\right)$ Whatman GF/C glass fibre filter. The particulate $\mathrm{C}$ and $\mathrm{N}$ on the filters was analysed using a CN-analyser (NA 1500 NC, Fisons Instruments). Filters were analysed after running a standard (acetanilide) with $71.09 \%$ of $\mathrm{C}$ and $10.36 \%$ of $\mathrm{N}$ in the machine. The particulate $\mathrm{P}$ analyses were performed according to the method described by Solorzano \& Sharp (1980). The filters containing the cells were placed in acid-washed glass scintillation vials with $2 \mathrm{ml}$ of $0.017 \mathrm{M} \mathrm{MgSO}_{4}$. The filters were then dried in the oven at $95^{\circ} \mathrm{C}$ and later placed in a muffleoven at $450^{\circ} \mathrm{C}$ for $2 \mathrm{~h}$. Then, $5 \mathrm{ml}$ of $0.2 \mathrm{M} \mathrm{HCl}$ were added to each sample, and $1 \mathrm{ml}$ was analysed using $\mathrm{PO}_{4}$ reagents for nutrient analysis (Valderrama 1995) and measured in a spectrophotometer (CADAS 100, Dr. Lange) at $882 \mathrm{~nm}$.

\section{Cell quantification}

Cell counts were carried out according to the Utermöhl method (Utermöhl 1958) to estimate nutrient contents in pmol cell ${ }^{-1}$ when using bulk methods. Samples were taken at the same time as those for elemental analysis and preserved in acidic Lugol's solution. Prior to sedimentation, the filaments were sonicated (Misonix Sonicator XL2020) for $30 \mathrm{~s}$ to break them into shorter lengths. A minimum of 400 filaments of each species was counted using an inverted microscope. The filaments were measured, and cell numbers were determined by dividing the total counted length by the length of 1 cell. These measurements were used to calculate the element content per cell obtained with both NMP and bulk methods.

\section{Statistical analysis}

The Mann-Whitney $U$-test was used to calculate the statistical difference between the 2 techniques for each element, and the significance level was set at 0.05 unless otherwise stated. The elemental contents and ratios of the 3 strains were compared using Kruskal-Wallis test ( $\mathrm{p}<0.05)$. For specific differences, Mann-Whitney $U$-tests were carried out $(\mathrm{p}<0.05$ ) unless otherwise stated. All statistical analyses were carried out using the computer program SPSS 19.

\section{RESULTS}

Cell densities at the time of sample collection were as follows: Anabaena sp. $5.9 \times 10^{5} \mathrm{cells} \mathrm{ml}^{-1}$, Nodularia spumigena $8.3 \times 10^{5}$ cells ml $\mathrm{m}^{-1}$ and Aphanizomenon flos-aquae var. klebahnii $14.4 \times 10^{5}$ cells $\mathrm{ml}^{-1}$.

For all 3 species, the elemental content measured with NMP showed higher variability than the bulk methods (Table 1, Fig. 1). The averages of the elemental contents of Anabaena sp. determined with NMP were $8 \%$ lower for $\mathrm{C}$ and $23 \%$ and $13 \%$ higher for $\mathrm{N}$ and $\mathrm{P}$, respectively, than those found with bulk methods. This difference generated lower $\mathrm{C}: \mathrm{N}$ and C:P ratios from the NMP analyses compared to those from the bulk methods (Table 1). The elemental contents were also comparable in the case of Nodularia spumigena. The NMP techniques 
Table 1. $\mathrm{C}, \mathrm{N}$ and $\mathrm{P}$ contents and ratios (mean $\pm \mathrm{SD}$ ) obtained using the nuclear microprobe (NMP) and bulk methods. The number of measurements is in parentheses. For the NMP, $\mathrm{n}$ refers to filaments; calculations express the content per cell

\begin{tabular}{|c|c|c|c|c|c|c|c|}
\hline Species & Method & pmol C cell ${ }^{-1}$ & pmol $\mathrm{N}$ cell ${ }^{-1}$ & pmol P cell ${ }^{-1}$ & $\mathrm{C}: \mathrm{N}$ & $\mathrm{N}: \mathrm{P}$ & $\mathrm{C}: \mathrm{P}$ \\
\hline \multirow[t]{2}{*}{$\begin{array}{l}\text { Anabaena } \\
\text { sp. }\end{array}$} & NMP & $\begin{array}{c}0.79 \pm 0.49 \\
(\mathrm{n}=14)\end{array}$ & $\begin{array}{c}0.22 \pm 0.08 \\
(\mathrm{n}=14)\end{array}$ & $\begin{array}{c}0.008 \pm 0.005 \\
(\mathrm{n}=14)\end{array}$ & $\begin{array}{c}3.43 \pm 1.31 \\
3.55^{\mathrm{a}}\end{array}$ & $\begin{array}{c}30.18 \pm 11.25 \\
26.73^{\mathrm{a}}\end{array}$ & $\begin{array}{c}94.23 \pm 23.08 \\
94.89^{\mathrm{a}}\end{array}$ \\
\hline & $\begin{array}{l}\text { Bulk method on } \\
\text { cell concentrate }\end{array}$ & $\begin{array}{c}0.86 \pm 0.03 \\
(\mathrm{n}=2)\end{array}$ & $\begin{array}{c}0.17 \pm 0.002 \\
(\mathrm{n}=2)\end{array}$ & $\begin{array}{c}0.007 \pm 0.001 \\
(\mathrm{n}=2)\end{array}$ & $\begin{array}{c}4.95 \pm 0.14 \\
4.95^{\mathrm{a}}\end{array}$ & $\begin{array}{c}26.43 \pm 5.93 \\
25.80^{\mathrm{a}}\end{array}$ & $\begin{array}{c}131.26 \pm 33.07 \\
127.74^{\mathrm{a}}\end{array}$ \\
\hline \multirow[t]{2}{*}{$\begin{array}{l}\text { Nodularia } \\
\text { spumigena }\end{array}$} & NMP & $\begin{array}{c}1.99 \pm 0.47 \\
(\mathrm{n}=16)\end{array}$ & $\begin{array}{l}0.38 \pm 1.30 \\
(\mathrm{n}=16)\end{array}$ & $\begin{array}{c}0.02 \pm 0.007 \\
(\mathrm{n}=16)\end{array}$ & $\begin{array}{c}5.61 \pm 1.55 \\
5.25^{\mathrm{a}}\end{array}$ & $\begin{array}{c}21.18 \pm 1.55 \\
19.61^{\mathrm{a}}\end{array}$ & $\begin{array}{c}111.36 \pm 33.00 \\
102.99^{\mathrm{a}}\end{array}$ \\
\hline & $\begin{array}{l}\text { Bulk method on } \\
\text { cell concentrate }\end{array}$ & $\begin{array}{c}2.04 \pm 0.13 \\
(\mathrm{n}=2)\end{array}$ & $\begin{array}{c}0.37 \pm 0.02 \\
(\mathrm{n}=2)\end{array}$ & $\begin{array}{c}0.027 \pm 0.000 \\
(\mathrm{n}=2)\end{array}$ & $\begin{array}{c}5.54 \pm 0.01 \\
5.54^{\mathrm{a}}\end{array}$ & $\begin{array}{c}13.50 \pm 0.81 \\
13.50^{\mathrm{a}}\end{array}$ & $\begin{array}{c}74.77 \pm 4.66 \\
74.77^{\mathrm{a}}\end{array}$ \\
\hline $\begin{array}{l}\text { Aphanizomenon } \\
\text { flos-aquae }\end{array}$ & NMP & $\begin{array}{c}0.33 \pm 0.23 \\
(\mathrm{n}=15)\end{array}$ & $\begin{array}{c}0.08 \pm 0.05 \\
(\mathrm{n}=15)\end{array}$ & $\begin{array}{c}0.0022 \pm 0.0018 \\
(\mathrm{n}=15)\end{array}$ & $\begin{array}{c}5.95 \pm 7.10 \\
4.21^{\mathrm{a}}\end{array}$ & $\begin{array}{c}48.01 \pm 21.51 \\
36.04^{\mathrm{a}}\end{array}$ & $\begin{array}{c}214.16 \pm 141.39 \\
151.68^{\mathrm{a}}\end{array}$ \\
\hline $\begin{array}{l}\text { var. } \\
\text { klebahnii }\end{array}$ & $\begin{array}{l}\text { Bulk method on } \\
\text { cell concentrate }\end{array}$ & $\begin{array}{c}0.63 \pm 0.001 \\
(\mathrm{n}=2)\end{array}$ & $\begin{array}{c}0.10 \pm 0.0001 \\
(\mathrm{n}=2)\end{array}$ & $\begin{array}{c}0.005 \pm 0.0006 \\
(\mathrm{n}=2)\end{array}$ & $\begin{array}{c}6.48 \pm 0.005 \\
6.48^{\mathrm{a}}\end{array}$ & $\begin{array}{c}19.32 \pm 2.40 \\
19.17^{\mathrm{a}}\end{array}$ & $\begin{array}{c}125.24 \pm 15.46 \\
124.27^{\mathrm{a}}\end{array}$ \\
\hline
\end{tabular}

gave $3 \%$ lower $\mathrm{C}, 3 \%$ higher $\mathrm{N}$ and $26 \%$ lower $\mathrm{P}$ content than the traditional methods. The calculated $\mathrm{C}: \mathrm{N}$ ratios were similar for the 2 methods, but the $\mathrm{N}: \mathrm{P}$ and $\mathrm{C}: \mathrm{P}$ ratios were higher when determined by the NMP techniques, as expected from the lower $\mathrm{P}$ content obtained with this technique (Table 1). In the case of Aphanizomenon flos-aquae, all the C, N and $\mathrm{P}$ contents measured with the NMP were lower than those obtained using bulk methods, i.e. C was $48 \%$, N was $21 \%$ and P was $60 \%$ (Table 1). Again,
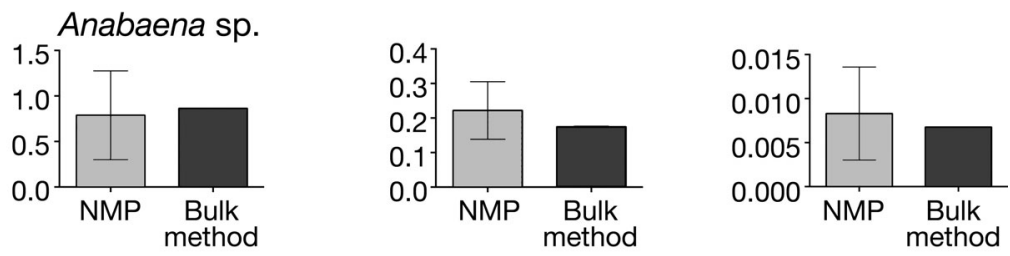

\section{Nodularia spumigena}
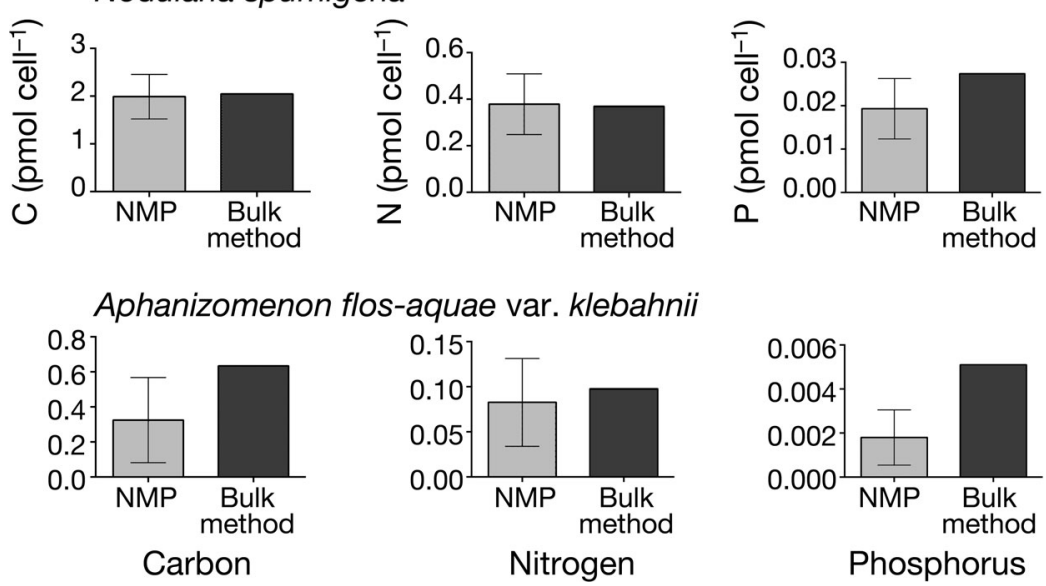

Fig. 1. Average $\mathrm{C}, \mathrm{N}$ and $\mathrm{P}$ content per cell (mean $\pm \mathrm{SD}$ ) of Anabaena sp., Aphanizomenon flos-aquae and Nodularia spumigena analysed using nuclear microprobe (NMP) techniques and bulk methods these differences were reflected in the ratios (Table 1). However, there was no significant difference between either the $\mathrm{C}, \mathrm{N}$ and $\mathrm{P}$ content obtained using bulk methods and the NMP or between the $\mathrm{C}: \mathrm{N}, \mathrm{N}: \mathrm{P}$ and $\mathrm{C}: \mathrm{P}$ ratios obtained with either of the analytical methods $(\mathrm{p}<0.05)$.

Differences in the $\mathrm{C}, \mathrm{N}$ and $\mathrm{P}$ cellular contents of the 3 species were observed (Figs. 1 \& 2). Nodularia spumigena showed the highest content per cell of all 3 elements, whereas Aphanizomenon flos-aquae showed the lowest. There was a statistically significant difference in the $\mathrm{C}, \mathrm{N}$ and $\mathrm{P}$ content between the 3 species $(\mathrm{p}<0.05)$. Regarding the C:N, $\mathrm{N}: \mathrm{P}$ and $\mathrm{C}: \mathrm{P}$ ratios, $N$. spumigena showed ratios closer than the other 2 species to the Redfield ratios (Table 1). Furthermore, there was a significant difference in the ratios between each species. Mann-Whitney $U$-tests showed that Anabaena sp. and N. spumigena had significantly different $\mathrm{C}: \mathrm{N}(U=$ 46, $\mathrm{p}<0.01)$ and $\mathrm{N}: \mathrm{P}$ ratios $(U=62$, $\mathrm{p}<0.01)$ but did not differ significantly in their C:P ratios. There were significant differences between Anabaena sp. and $A$. flos-aquae in terms of their N:P $(U=66, \mathrm{p}<0.05)$ and $\mathrm{C}: \mathrm{P}$ ratios $(U=59, \mathrm{p}<0.01)$ but not their C:N ratio. Finally, N. spumigena had significantly different $\mathrm{N}: \mathrm{P}(U=41, \mathrm{p}<$ $0.01)$ and $\mathrm{C}: \mathrm{P}$ ratios $(U=90, \mathrm{p}<0.05)$ than A. flos-aquae, but this difference was not observed for these species' $\mathrm{C}: \mathrm{N}$ ratios. 

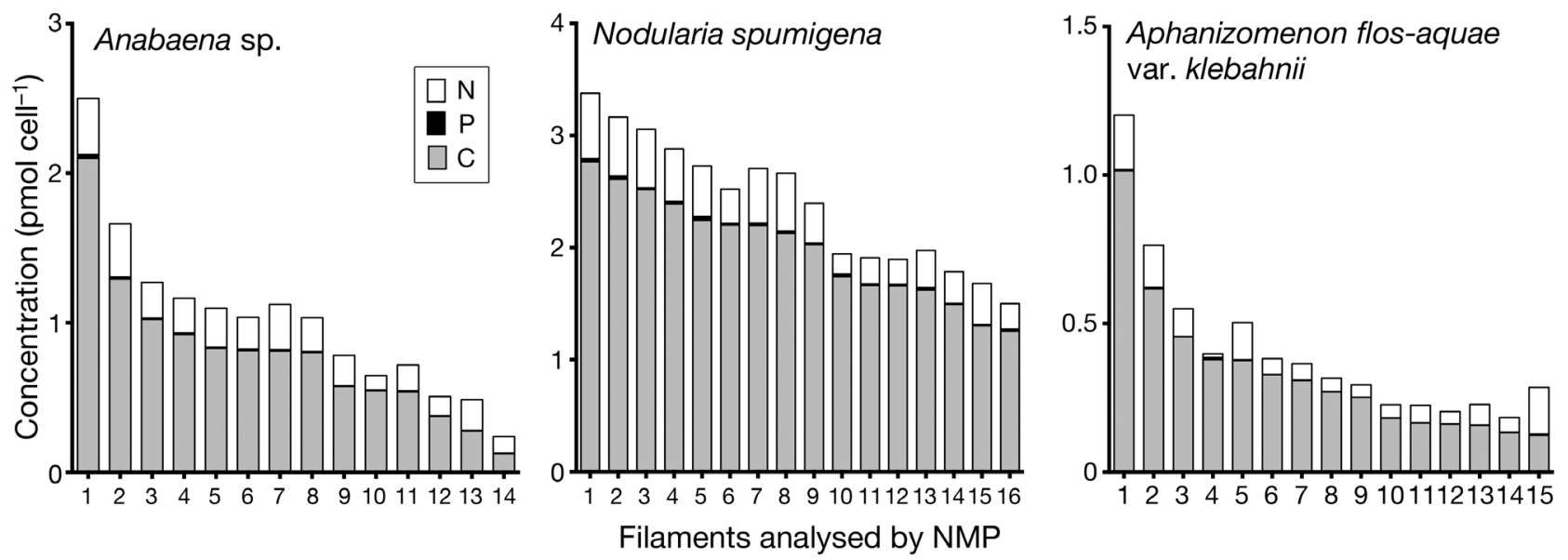

Fig. 2. Average C, N and P content per cell found in each of the filaments of Anabaena sp., Aphanizomenon flos-aquae and Nodularia spumigena analysed using nuclear microprobe (NMP) techniques

\section{DISCUSSION}

The carbon content values obtained in the present study differed from those estimated by Edler (1977) on natural samples from the Baltic Sea (measurement of cells and use of a stoichiometric formula) for Anabaena sp. (0.33 pmol C cell $\left.{ }^{-1}\right)$ and for Aphanizomenon flos-aquae $\left(1.67 \mathrm{pmol} \mathrm{C}\right.$ cell $\left.^{-1}\right)$ but were similar for Nodularia spumigena (2.92 pmol C cell-1). However, a $\mathrm{C}$ content at least 4 -fold higher has also been reported for N. spumigena (Panosso \& Granéli 2000), even though the C:N (5.5) and N:P (14) ratios reported by these authors were both similar to those found in the present study.

The filaments analysed here were growing exponentially in nutrient-replete cultures and should therefore show the optimum nutrient content in the cells. Nevertheless, we observed high variability in the element contents per cell from different filaments when using the NMP techniques. Intraspecific variability was also reported in Dinophysis norvegica intracellular N content by Gisselson et al. (2001) based on measurements with NMP techniques. This was also found when using XRMA techniques to measure the $\mathrm{Na}, \mathrm{Mg}, \mathrm{Si}, \mathrm{P}, \mathrm{S}, \mathrm{Cl}, \mathrm{K}$ and $\mathrm{P}$ cellular content of Asterionella formosa (Krivtsov et al. 2000) or the $\mathrm{P}$ and $\mathrm{K}$ content in different samples of Ceratium hirundinella (Sigee et al. 1998). We believe that these variations are partly due to the much lower number of cells that can be analysed using these methods because only one cell, or in this case, filament, is scanned at a time, which is time consuming. However, cyanobacteria are small in comparison with the diatoms or dinoflagellates analysed in the 3 studies mentioned above, and each filament analysed con- tained several cells (no less than 14 cells and up to 100), thus increasing the number of cells analysed in the present study and therefore reducing the error due to low sample size. Still, the amount of cells analysed with NMP techniques cannot be compared with the thousands or millions of cells analysed with bulk methods or with the reproducibility of those methods. More importantly, the NMP techniques allowed us to obtain the actual content of individual filaments, showing the variability within the population, and these techniques should be preferred in cases where elemental content of individuals might be of interest. However, the elemental content under determined conditions cannot be taken as the only reference for a species. It has been observed that with decreasing temperatures, the $\mathrm{C}, \mathrm{N}$ and $\mathrm{P}$ content of Scenedesmus sp. and of Asterionella formosa, increased under nutrient-sufficient conditions (Rhee \& Gotham 1981).

All 3 species were $\mathrm{N}$ replete, and only Aphanizomenon flos-aquae seemed $\mathrm{P}$ depleted according to the Redfield ratios, although all showed N:P ratios above 16, probably due to an excess of $\mathrm{N}$ rather than to P depletion. However, Wallström (1998) found that an N:P ratio of 10:1 in the water corresponded to favourable conditions for $\mathrm{N}$-fixing algae, whereas a lower ratio, opposite to our case, would indicate $\mathrm{P}$ excess. Wallström's (1998) study was carried out with Aphanizomenon flos-aquae, a species whose growth was less stimulated by phosphorus input than that of Nodularia and Anabaena (Wasmund et al. 2012). These observations, as well as the differences observed in the cellular nutrient content in the present study, might show different requirements for each of these species as well as differences in their efficiency 
for nutrient uptake. For instance, N. spumigena is a superior competitor to A. flos-aquae at low phosphorus concentrations because it is more efficient at utilising organic sources and grows better on intracellular stores (Vahtera et al. 2007). This is in agreement with the high phosphorus content found in N. spumigena in comparison with that found in Anabaena sp. and A. flos-aquae, given that all were growing under the same conditions.

The NMP techniques analyse one cell or filament at a time and are costly in comparison with the bulk methods, reducing the number of cells that can be analysed with these techniques. Also, the NMP here used a proton beam of $5 \mu \mathrm{m}$, analysing squares of $25 \mu^{2}{ }^{2}$, so it could have underestimated elemental content when analysing cells narrower than $5 \mu \mathrm{m}$ or if part of the surface analysed did not belong to the cell, but we do not believe that this was a problem when analysing the filaments in the present study. Also, while bulk methods need filtrates of large volumes of water, elemental analyses can be carried out with the NMP techniques by recovering the targeted cells when only a small volume is available.

We conclude that the NMP is a potentially useful tool to measure phytoplankton nutrient status using field samples. Not only is it comparable with traditional bulk methods, but it is also species-specific and will show the variability within a given population. Furthermore, these techniques could be used to observe changes in intracellular nutrient content along the life cycle of a single species in more detail than the possibilities offered by traditional methods.

Acknowledgements. The authors thank C. Esplund for her technical support. This work was financed by the EU NUTOX project, contract MAS3-CT97-0103, and by the Swedish Natural Science Research Council (NFR).

\section{LITERATURE CITED}

Arrigo KR (2005) Marine microorganisms and global nutrient cycles. Nature 437:349-355

Clay S, Sigee DC, Bellinger E (1991) X-ray microanalytical studies of fresh-water biota: changes in the elemental composition of Anabaena spiroides during blooms of 1988 and 1989. Scanning Microsc 5:207-217

Droop MR (1973) Nutrient limitation in osmotropic protista. Am Zool 13:209-214

Droop MR (1974) Nutrient status of algal cells in continuous culture. J Mar Biol Assoc UK 54:825-855

Edler L (1977) Phytoplankton and primary production in the Sound. PhD dissertation, University of Gothenburg

El-Bestawy E, Bellinger EG, Sigee DC (1996) Elemental composition of phytoplankton in a subtropical lake: Xray microanalytical studies on the dominant algae Spirulina platensis (Cyanophyta) and Cyclotella meneghini- ana (Bacillariophyceae). Eur J Phycol 31:157-166

Engström-Öst J, Repka S, Mikkonen M (2011) Interactions between plankton and cyanobacterium Anabaena with focus on salinity, growth and toxin production. Harmful Algae 10:530-535

Ganf GG, Stone SJL, Oliver RL (1986) Use of protein to carbohydrate ratios to analyze for nutrient deficiency in phytoplankton. Aust J Mar Freshw Res 37:183-197

> Gisselson LA, Granéli E, Pallon J (2001) Variation in cellular nutrient status within a population of Dinophysis norvegica (Dinophyceae) growing in situ: single-cell elemental analysis by use of a nuclear microprobe. Limnol Oceanogr 46:1237-1242

Holm NP, Armstrong DE (1981) Effects of Si-P concentration ratios and nutrient limitation on the cellular composition and morphology of Asterionella formosa (Bacillariophyceae). J Phycol 17:420-424

Klausmeier CA, Litchman E, Daufresne T, Levin SA (2004) Optimal nitrogen-to-phosphorus stoichiometry of phytoplankton. Nature 429:171-174

Krivtsov V, Bellinger EG, Sigee DC (2000) Changes in the elemental composition of Asterionella formosa during the diatom spring bloom. J Plankton Res 22:169-184

Llabador Y, Moretto P (1998) Applications of nuclear microprobes in the life sciences: an efficient analytical technique for research in biology and medicine. World Scientific Publishing, Singapore

> Moretto P, Llabador Y (1997) The nuclear microprobe: an insight of applications in cell biology. Nucl Instrum Methods Phys Res B 130:324-334

Pallon J, Malmqvist KG, Werner-Linde Y, Forslind B (1996) Pixe analysis of pathological skin with special reference to psoriasis and atopic dry skin. Cell Mol Biol 42: 111-118

Pallon J, Elfman M, Kristiansson P, Malmqvist K, Granéli E, Sellborn A, Karlsson C (1999) Elemental analysis of single phytoplankton cells using the Lund nuclear microprobe. Nucl Instrum Methods Phys Res B 158:312-316

Pallon J, Auzelyte V, Elfman M, Garmer M and others (2004) An off-axis stim procedure for precise mass determination and imaging. Nuc Instruments Methods Phys Res Section B: Beam Interactions with Materials and Atoms 219-220:988-993

Panosso R, Granéli E (2000) Effects of dissolved organic matter on the growth of Nodularia spumigena (Cyanophyceae) cultivated under $\mathrm{N}$ or P deficiency. Mar Biol 136:331-336

Redfield AC, Ketchum B, Richards F (1963) The influence of organisms on the composition of seawater. In: Hill MN (ed) The sea. Wiley, New York, NY, p 26-77

> Rengefors K, McCall RD, Heaney SI (1999) Quantitative Xray microanalysis as a method for measuring phosphorus in dinoflagellate resting cysts. Eur J Phycol 34:171-177

Rhee GY (1978) Effects of N:P atomic ratios and nitrate limitation on algal growth, cell composition, nitrate uptake. Limnol Oceanogr 23:10-25

Rhee GY, Gotham IJ (1981) The effect of environmental factors on phytoplankton growth: temperature and the interactions of temperature with nutrient limitation. Limnol Oceanogr 26:635-648

> Sakshaug E, Olsen Y (1986) Nutrient status of phytoplankton blooms in Norwegian waters and algal strategies for nutrient competition. Can J Fish Aquat Sci 43:389-396

Seppälä J, Tamminen T, Kaitala S (1999) Experimental evaluation of nutrient limitation of phytoplankton communi- 
ties in the Gulf of Riga. J Mar Syst 23:107-126

Sigee DC, Holland R (1997) Elemental composition, correlations, and ratios within a population of Staurastrum planctonicum (Zygnematales): an X-ray microanalytical study. J Phycol 33:182-190

Sigee DC, Krivtsov V, Bellinger EG (1998) Elemental concentrations, correlations and ratios in micropopulations of Ceratium hirundinella (Pyrrhophyta): an X-ray microanalytical study. Eur J Phycol 33:155-164

Smith VH (1983) Low nitrogen to phosphorus ratios favor dominance by blue-green algae in lake phytoplankton. Science 221:669-671

Solorzano L, Sharp JH (1980) Determination of total dissolved phosphorus and particulate phosphorus in natural waters. Limnol Oceanogr 25:754-758

Tapper UAS, Malmqvist KG (1991) Analysis, imaging, and modification of microscopic specimens with accelerator beams. Anal Chem 63:715A-725A

Tett P, Heaney SI, Droop MR (1985) The Redfield ratio and

Editorial responsibility: Patricia Glibert,

Cambridge, Maryland, USA phytoplankton growth rate. J Mar Biol Assoc UK 65: 487-504

Utermöhl H (1958) Zur Vervollkommnung der quantitativen Phytoplankton-Methodik. Mitt Int Ver Theor Angew Limnol 9:1-38

Vahtera E, Laamanen M, Rintala JM (2007) Use of different phosphorus sources by the bloom-forming cyanobacteria Aphanizomenon flos-aquae and Nodularia spumigena. Aquat Microb Ecol 46:225-237

Valderrama JC (1995) Methods of nutrient analysis. In: Hallegraeff GM, Anderson DM, Cembella AD (eds) Manual on harmful marine microalgae. IOC and guides, UNESCO, Paris, p 251-268

Wallström K (1988) The occurrence of Aphanizomenon flosaquae (cyanophyceae) in a nutrient gradient in the Baltic. Kieler Meeresforsch Sonderh 6:210-220

Wasmund N, Nausch G, Voss M (2012) Upwelling events may cause cyanobacteria blooms in the Baltic sea. J Mar Syst 90:67-76

Submitted: January 9, 2013; Accepted: September 17, 2013 Proofs received from author(s): November 20, 2013 